


\section{El uentorno de trabajo PBLI): un sistema experto para aprender la pedagogía del aprendizaje basado en problemas}

\section{Extracto:}

El «entorno de trabajo PBL» es un entorno virtual diseñado en el marco de referencia del proyecto SCENE (ProfeSsional development for an effeCtive PBL approach: a practical experiENce through ICT-enabled IEarning solution), cofinanciado por el Programa Europeo de Aprendizaje. El «entorno de trabajo PBL» se dedica a preparar a los directores y profesores de las escuelas de secundaria y formación profesional para que usen el aprendizaje basado en problemas [PBL o ABP (en español)] de una manera pedagógica efectiva. Se trata de una pedagogía centrada en el alumno, donde los estudiantes se dedican a resolver problemas del mundo real o a cumplir retos.

El «entorno de trabajo PBL» es una herramienta virtual que consta de tres elementos principales: la plataforma e-learning, el Facilitador Virtual y el repositorio PBL. Permite a los profesores, formadores y directores aprender la pedagogía PBL asistiendo a un curso on-line (plataforma e-learning) a través del «método inductivo». A los estudiantes les permite experimentar desde el enfoque PBL, practicando etapa por etapa, y posteriormente aprender a convertir la práctica en teoría mediante la abstracción de su experiencia para construir un conocimiento teórico. Generar el escenario adecuado es el aspecto más crítico del PBL. Tras beneficiarse del curso on-line, los usuarios pueden aprovecharse de un soporte más: el Facilitador Virtual. Este proporciona consejos y sugerencias sobre cómo diseñar correctamente un escenario problemático y, mediante preguntas, para recoger datos de las necesidades específicas de los usuarios, el Facilitador Virtual es capaz de proporcionar uno o más ejemplos que sean lo más adecuados a las necesidades del profesor. Por último, los usuarios pueden compartir escenarios problemáticos y proyectos de diferentes temas de estudio, y con distintas características, que hayan sido cargados y descargados en el repositorio PBL.

Palabras claves: ambiente colaborativo de aprendizaje, aprendizaje basado en problemas (PBL), aprendizaje activo, formación de profesores y de instructores.

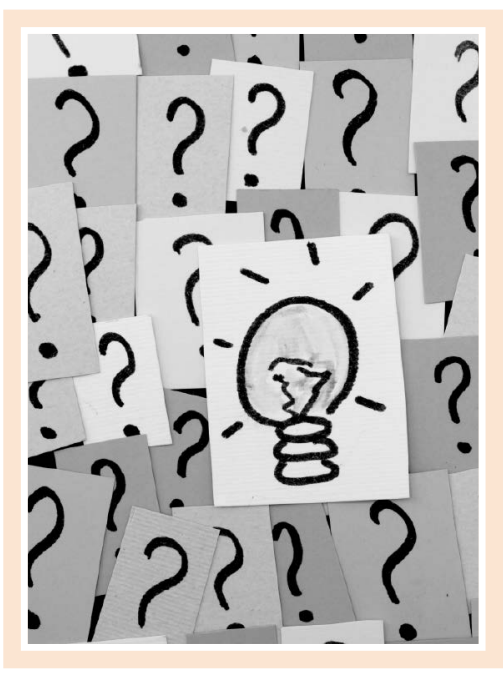

\section{THE PROBLEM- BASED LEARNING}

$\mathrm{PBL}$ is perhaps the most innovative instructional method conceived in the history of education. It is based on the constructivist approach of learning where:

- Knowledge is individually constructed and socially co-constructed from interactions with the environment; knowledge cannot be transmitted.

- There are necessarily multiple perspectives related to every phenomenon.

- Meaning and thinking are distributed among the culture and community in which we exist and the tools that we use.

- Knowledge is anchored in and indexed by relevant contexts.

Following the main principles of this approach, the PBL is a student-cantered pedagogy where learners are "actively» engaged in real world problems to solve or challenges to meet. Students develop problem-solving, self-directed learning and team skills (Barrows and Tamblyn 1980), (Schmidt, 1983, pp. 11-16; 
Neville, 2009). The modern history of PBL begins in the early 1960s at the medical school at McMaster University in Canada (Gallagher, Sher, Stepien and Workman, 1995, pp. 136-146). Its effectiveness in facilitating student problem-solving and self-directed learning skills has been widely reported in medical education (Barrows and Tamblyn 1980). PBL has also become increasingly popular across disciplines in higher education and K-12 education settings (Gallagher, Sher, Stepien and Workman, 1995, pp. 136-146; Dochy, Segers, van den Bossche and Gijbels, 2003, pp. 533568). But, until recently the PBL approach has flourished mainly in medical and professional schools. Slowly the sciences in general have begun taking it up, and even more slowly, the humanities.

The research results on the effects of PBL on learners performance showed that in terms of short-term retention, no difference was found between PBL and traditional learners. However PBL learners consistently outperformed traditional students on long-term retention assessments. In fact the PBL has shown a positive impact on learners' abilities to apply basic science knowledge and transfer problem-solving skills in real world professional or personal situations. The main advantages of $\mathrm{PBL}$ pedagogy can be resumed as follow:

- PBL enhances potential value of real world problems in terms of sustained learning and potential impact on interest.

- Learners don't develop knowledge but capacities to apply knowledge in working context.

- Learners develop deep Problem-solving skills.

- Learners experience self-directed learning skills and team skills (needed in their professionals lives).

- Students personal involvement is enhanced.

- Fulfilment of tasks and duties is focused on real activities.

The use of the PBL or of a constructivist approach in the European secondary schools is not too diffuse as it should it be. While it is possible to do PBL in almost any school environment, it is most feasible and most effective when certain school conditions are in place (Larmer and Mergendoller, 2010, pp. 34-37). Moreover, teachers need to be prepared to implement $\mathrm{PBL}$. «PBL provides an opportunity for educators to redefine the nature of learning and, in turn, reposition their roles in teaching from a knowledge/information transmitter to a learning/thinking process facilitator» (Hung, Jonassen and Liu, 2008, p. 493). This shift requires PBL tutors reconsider their educational roles. The PBL tutor must balance a degree of participation in students' learning processes and refrain from the temptation to lecture. The effective communication skills are the necessary assumption for effective tutoring. Tutor's authentic interactions are revealed in their ability to communicate with students informally while maintaining an empathetic attitude. In addition, effective tutors must be willing to be actively involved with students (Hung, Jonassen and Liu, 2008, pp. 485-506).

\section{PBL is perhaps the most innovative instructional method conceived in the history of education}

PBL prepare students for problem solving and continuous professional development is required for all professions, including trainers and teachers. Self-directed learning, drawing on previous experiences, valuing learning that integrates into their everyday life and preferring problem-centered learning, learners identifying their own learning objectives, and identifying resources and devising strategies to use them. These assumptions and guidance are integral to learning through PBL, and moreover prepare the student for problem solving and continuous professional development.

PBL model needs schools and classrooms preparation. This preparation must be done in the School level, so that PBL could be consistently and successfully implemented. Moving from individual schools to mass implementation of main course PBL will require vision and leadership at the district, state and eventually, the national level. An example from the USA-West Virginia a multi-faceted initiative to better prepare students to meet 21 st century educational goals, by redesigning West Virginia school. It has implied rethinking and revising state standards and assessment, teacher credentialing and professional development. They have included relying on wikis and other technologies to share information, disseminate approved project designs and support teachers, West Virginia educators and students (Larmer and Mergendoller, 2010, pp. 34-37). 


\section{SCENE «PBL WORKING ENVIRONMENT»}

The on-line «PBL working environment» represents the main product of the SCENE project. SCENE «ProfeSsional development for an effeCtive PBL approach: a practical experiENce through ICT-enabled IEarning solutions» (http://www.forcom.it/area-ricerca-e-sviluppo/progetti-internazionali ) is a two years and half project (from January 2012 to June 2014) co-funded by the European Lifelong Learning Program (Key Activity 3: ICT). It is leaded by FOR.COM. a public interuniversity consortium, of which Università degli Studi Guglielmo Marconi is member.

The SCENE project aims to prepare headmasters and teachers in European secondary and vocational schools to use PBL pedagogy effectively by developing an innovative on-line learning environment.

The SCENE «PBL working environment» is an integrated virtual tool (Feituri, Kear and Rudman, 2012) which consists of three distinct elements (e-learning platform, Virtual Facilitator and PBL repository).
«PBL working environment» allows teachers, trainers and headmasters/school managers to understand the PBL approach and to be able to apply it efficiently in classroom. With the «PBL working environment» teachers, trainers and headmasters/school managers can:

- Learn the PBL pedagogy by practicing it with an online course delivered through the «inductive method» focused on virtual tasks to accomplish (e-learning platform).

- Benefit from a guidance and support service after the course attending thanks to a virtual system (Virtual Facilitator) expert in PBL.

- Share problem scenarios and projects of different subjects of studies and with different characteristics uploaded and downloaded in the PBL repository.

\section{Figure 1. «PBL working environment» home page}
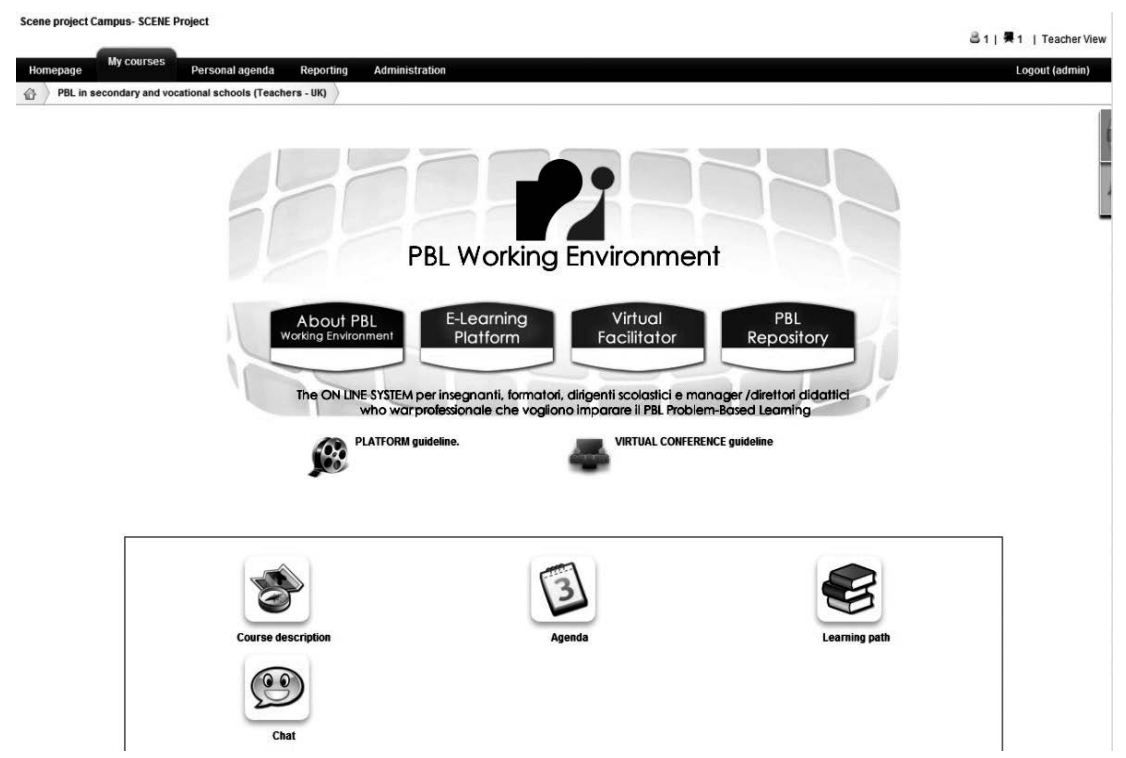

Source: elaborated by the author. 


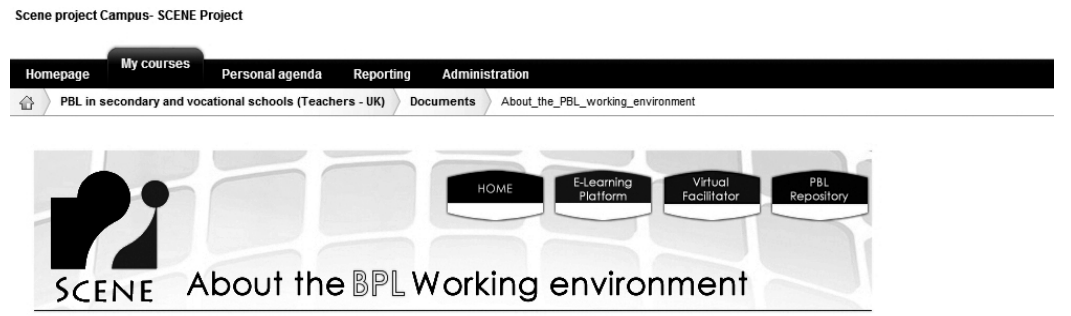

Would you like to learn the PBL pedagogy by practicing it?

Is it the first time you apply the PBL in your classroom?

Or you know the PBL but you are not enough expert to use it properly.

Would you like to get new ideas and suggestions to design problem scenarios for your subject?

Would you like to share and compare your PBL experiences?

THE "PBL WORKING ENVIRONMENT" IS ALL OF THESE THINGS.

The PBL WORKING ENVIRONMENT allows you to:

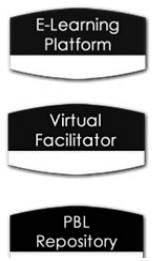

EXPERIENCE THE PBL by conducting practical activities and then abstract the experience to build a theoretical understanding

GET PRACTICAL ADVISES on how to design problem scenarios and manage your PBL classroom

GET PROPER EXAMPLES of problem scenarios for different concepts and subject areas

\subsection{E-learning platform and on-line course}

The SCENE on-line course is delivered through the E-Learning Platform, created by using the "Chamilo» open source Learning Management System (LMS). The SCENE e-course is entitled «Problem-Based Learning in secondary and vocational schools: a studentcentered pedagogy based on real-world experiences» (Bastos, Correnti, Dias, Mergendoller and Rudman, 2012) and includes 5 modules:

- Module 0: Familiarization and Socialization.

- Module 1: Self-reflection and introduction to PBL.

- Module 2: Designing a Problem Scenario.

- Module 3: Assessing a Problem Scenario.

- Module 4: Managing a Problem Scenario.
The SCENE course training methodology (Correnti, Feituri, Dias, Edirisingha and Mercengendoller, 2012), based on a constructivist approach, is the inductive method. It allows learners to experience PBL methodology, by practicing it stage by stage, and then learn to turn practice into theory by abstracting their experience to build a theoretical understanding. Thus, this method allows students to be actively engaged in tasks and to build knowledge on the base of experienced practical examples.

According to the «Inductive learning approach» each module of the SCENE on-line course includes practical and theoretical contents. Participants start each modu- 
le by benefiting from the practical multimedia contents and tasks; following they have the opportunity to reflect on their actions and generate understanding by benefiting from multimedia lessons and lecture notes (Theoretical Learning Objects). This process encourages them to connect their new knowledge and their existing knowledge, thus extending their theoretical understanding (action->reflection->new knowledge).

The course total duration is 64 hours. The practical session lasts 40 hours and includes links to web interesting documents, articles, videos (as case studies of different subject areas), assignments and online discussions delivered through a virtual forum where participants are expected to accomplish tasks and solve different problem scenarios according each own subject of study. The practical tasks and scenarios accomplished are multilingual (English, Greek, Italian, Portuguese, Romanian, Turkish) while case studies of different subject areas are in English.

National virtual classrooms are arranged among each target group participants (teachers /trainers and headmasters/school managers) to promote the reflection, discussion, synthesis and integration of the achieved results from practical exercises (arranged in National language). They are «practical» because allow course participants to share ideas and experiences and by doing this to improve participants his/her own scenarios. At the same time participants can discuss on the main principles as based of the practical experienced just done and so they can infer from this the theoretical knowledge («turn practice into theory»). As added value at least three international virtual classrooms are arranged among course participants of different countries to allow the sharing of knowledge and experience across national boundaries.

The Theoretical Session of the course lasts 24 hours and includes in-depth study of problem based learning's guiding ideas, main principles and its theoretical knowledge base (Lecture Notes and Multimedia Lessons). The multimedia lessons are multilingual with links to videos, articles and interested web pages in English. Finally the lecture notes (one per module) summarizes the main theoretical knowledge and concepts and they are multilingual.

SCENE partners decided to develop a specific training path for headmasters and vocational school managers. This course has been developed taking into account their specific and actual needs such as the reduced time available and the less flexibility to take part in training courses. In detail, it includes the following modules:

- Module 0: Familiarization and Socialization.

- Module 1: Self-reflection and introduction to PBL.

- Module 2: Designing a Problem Scenario.

- Module 3: Assessing a Problem Scenario.

- Module 4: Managing a Problem Scenario.

- Module 5: Towards a «constructivist school»; Workshop for the PBL promotion in within the school; Research Materials.

Figure 3. «PBL working environment» on-line course

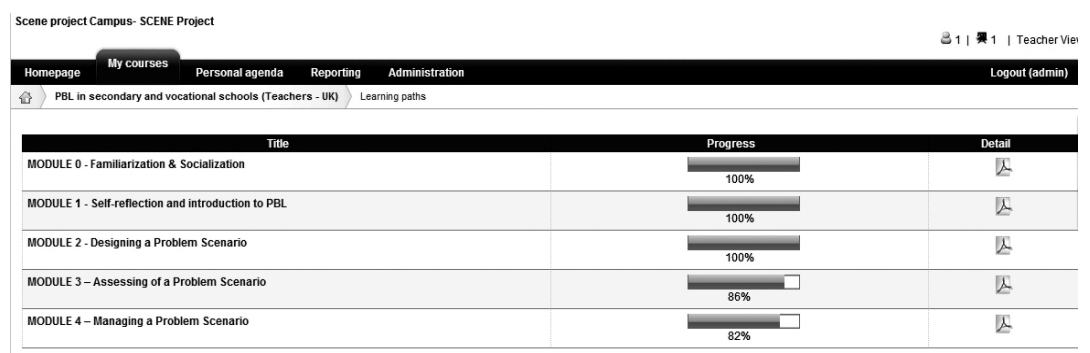




\subsection{Virtual Facilitator}

Generating the proper scenario is the most critical aspect of PBL.

The PBL scenario must invite genuine inquiry and it has to drive learners to determine what they think they know about the described event, what they will need to know in order to identify problems and how they'll investigate the problem.

The design and implementation of an appropriate scenario is central to effective PBL. For this reason, after benefiting from the on-line course (e-learning platform) the teachers, trainers and headmasters/vocational school managers have the opportunity to apply the PBL with their students creating their own problem scenario, but they aren't alone.

As «newbies PBL facilitators» the «PBL working environment» offers them a further support/guidance service for the first time (but not only) they want to apply the PBL with their students: the "Virtual Facilitator». It is an expert system who guides the teachers, trainers and headmasters/vocational school managers, who (after the course benefiting from) want to apply the PBL methodology, just learned, with their students. We believe that as «newbie PBL facilitators» they need support and guidance from a PBL expert. Thus, the Virtual Facilitator provides a further and key service (in addition to the ecourse) for who wants to use the PBL in their classrooms.
The Virtual Facilitator features two main roles, as follow:

- As ADVISOR, the Virtual Facilitator provides tips and hints on how correctly design a problem scenario and also the link to the specific content of the e-course they can review for in depth information.

- As PROFILER, by asking questions to collect data on user's specific needs, the Virtual Facilitator is able to provide al or more suitable example(s) which match as closest as possible the teacher/ trainer need.

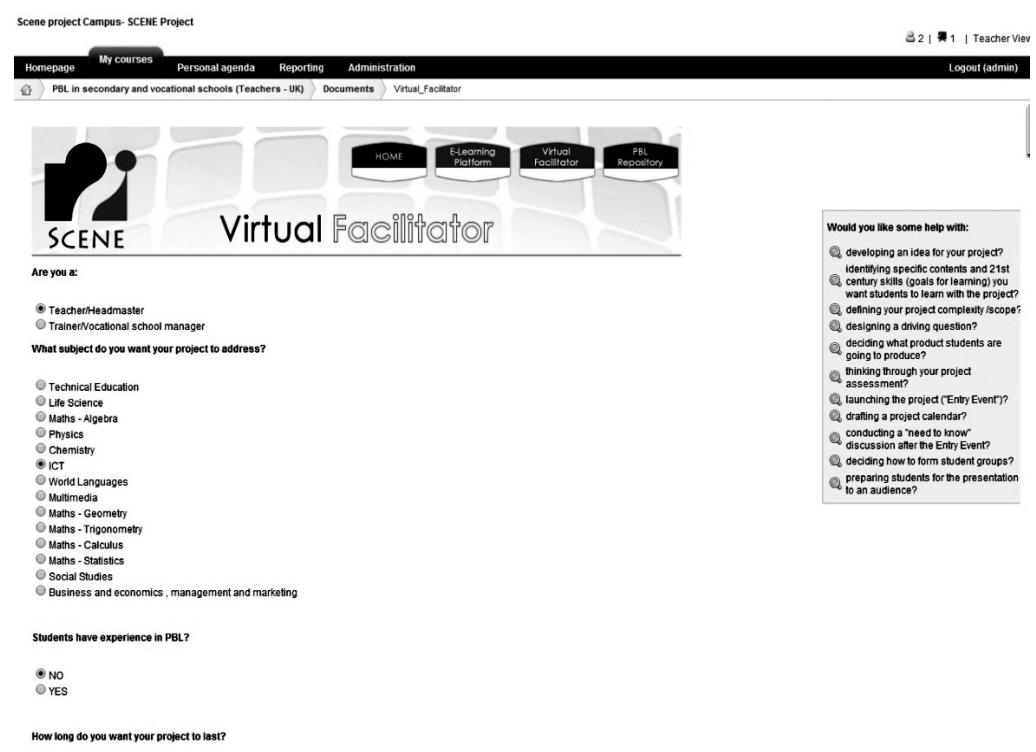

Source: elaborated by the author. 


\subsection{PBL repository}

The third element of the «PBL working environment» is the PBL repository, strictly connected to the Virtual Facilitator.

The PBL Repository is a sharing area where teachers, trainers and headmasters/vocational school managers can upload their own PBL scenarios/projects and download the others. In particular the PBL repository aims to contain a lot of projects/problems scenario enough to cover all the target group needs. The aim is at encouraging the target group to fill the PBL repository with new project ideas or modifications of the projects already proposed. To do so, teachers/trainers can access the PBL repository and fill in a form with metadata to be uploaded together with the project idea. In this way the PBL repository can continuously updated with more and more projects fulfilling different teachers needs.

The Virtual Facilitator role is to retrieve project examples, uploaded in the PBL repository, from a growing set and provide it/them to the teacher/trainer, who are «asking» its help/support. This/these project(s)/problem(s) is/are the closest example to the teacher/trainer really needs.

The repository aims is to become a reference to those teachers and trainers who want to find problem scenarios/projects for delivering PBL sessions to their students.

\section{Figure 5. «PBL working environment» PBL repository}

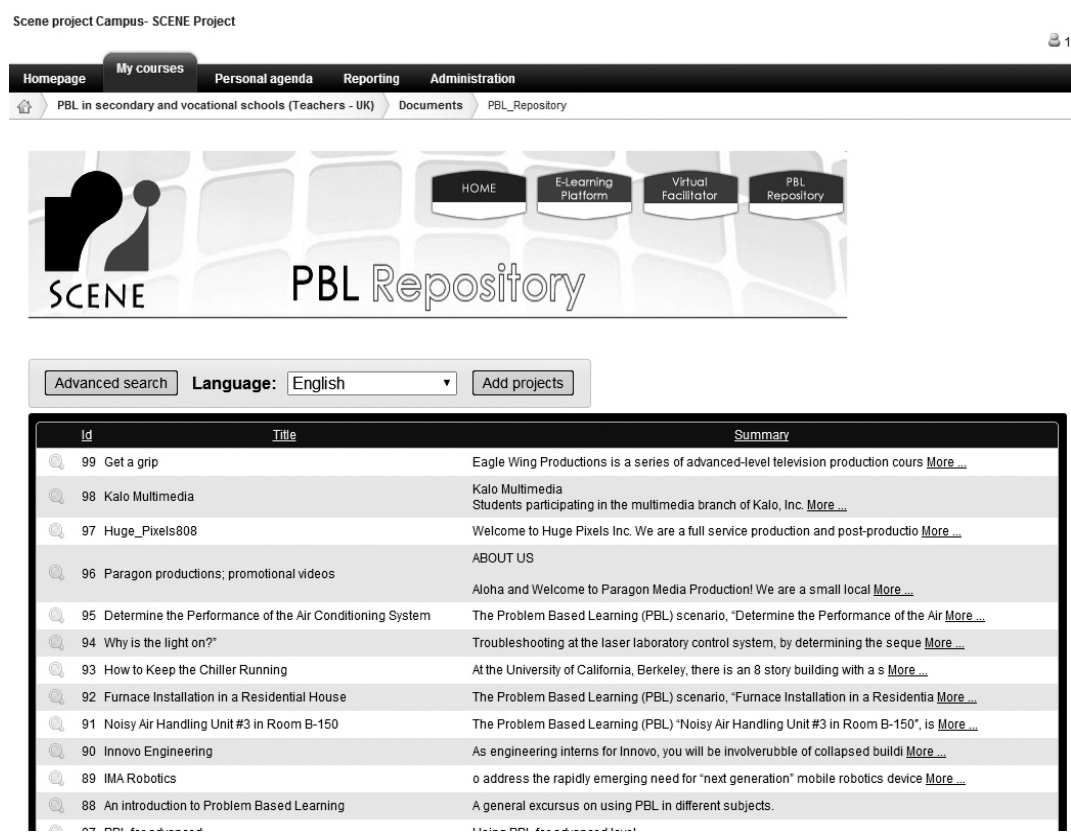

Source: elaborated by the author. 


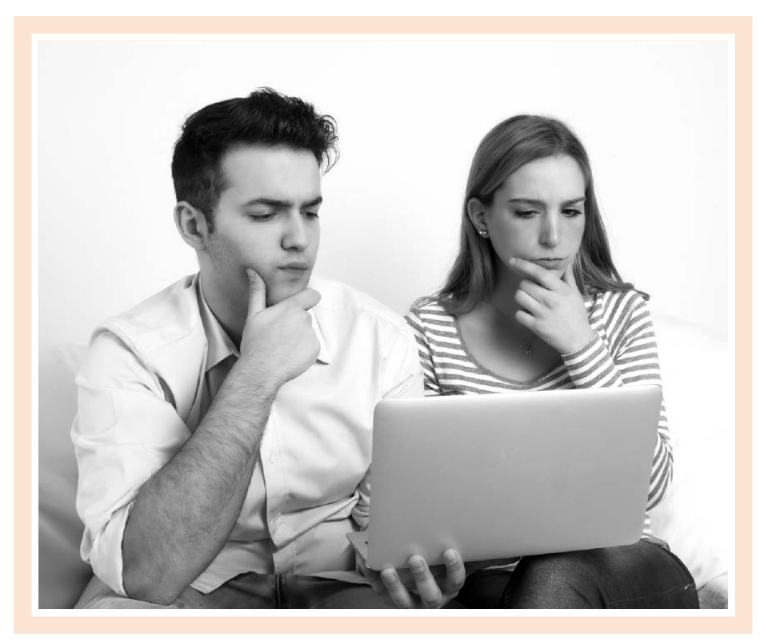

\section{CONCLUSION}

The expert system «PBL working environment» was born starting from the emergent need to improve the teachers, trainers and all actors of the educational context who have to overcome the emergent challenges of the teaching profession. Teachers and trainers are required to use the opportunities offered by new technologies and to respond to the demand for individualised and «practical» learning. The constructivist approach requires students to work actively to build their own understanding instead of passively listening lectures. The PBL is perhaps the most innovative instructional constructivist approach conceived in the history of education. To train teachers, trainers and all educational actors on the PBL pedagogy could be an important step to modernise the educational system toward a «constructivist school».

Starting from these pivotal assumptions the expert system «PBL working environment» wants to provide teachers and trainers innovative tools to learn the PBL. Following the same principles of the constructivist approach, it allows users to «experience» and «practice» the PBL through an on-line course where participants, according to the «inductive learning approach», accomplish several tasks built on real-world cases and following they can infer the theoretical knowledge; the Virtual Facilitator provides an additional guidance and support service to «Newby Facilitators» (just learned and/or not enough expert on PBL) who want apply the PBL with their students. Designing a problem scenario is a pivotal step for applying the PBL successfully. The Virtual Facilitator provides useful and practical tips on the different steps of the
PBL and the user one or more examples of scenarios/projects that best fit with his/her specific need by retrieving them from the PBL repository. Moreover, the PBL repository allow users to share problem scenarios and projects of different subjects of studies and with different characteristics.

The expert system aims to be the benchmark for those who want to learn the PBL pedagogy autonomously or those who already knows the PBL main principles but need a further support and guidance or simply those who apply the PBL regularly in classroom but want to share projects and suggestions with other teachers to improve their practice and find new ideas.

The designing of a genuine problem scenario is essentially linked to the teachers "creativity» but we believe that the personal creativity have to be enriched and cultivate thanks to the comparison and sharing of experiences with pears. The «PBL working environment» can be continually improved and enriched by its users who, by filling up the PBL repository with different scenarios in different languages, provide the Virtual Facilitator with a higher number of problem scenarios examples to retriever. Then, the Virtual Facilitator will became more and more efficient.

\section{The Virtual Facilitator provides useful and practical tips on the different steps of the PBL and the user one or more examples of scenarios/ projects that best fit with his/her specific need by retrieving them from the PBL repository}




\section{REFERENCES}

Barrows, H. S. and Tamblyn, R. M. [1980]: Problem-based learning: an approach to medical education. New York, Mass.: Springer.

Bastos A. S., Correnti S., Dias, P., Mergendoller J.R. and Rudman, P. [2012]: Course curriculum. Produced in the framework of SCENE project, N. 519367-LLP-1-20111-IT-KA3-KA3MP.

Correnti S., Feituri M., Dias, P., Edirisingha P. and Mergendoller J. R. [2012]: Instructional design handbook. Produced in the framework of SCENE project, $\mathrm{N}$. 519367-LLP-1-2011-1-IT-KA3-KA3MP.

Dochy, F., Segers, M., van den Bossche, P. and Gijbels, D. [2003]: «Effects of problem-based learning: a metaanalysis», Learning and Instruction, 13, pp. 533-568.

Feituri, M., Kear, S. and Rudman, P. [2012]: Executive project. Produced in the framework of SCENE project, N. 519367-LLP-1-2011-1-IT-KA3-KA3MP.
Gallagher, S. A., Sher, B. T., Stepien, W. J. and Workman, D. [1995]: «Implementing problem-based learning in the science classroom», School Sciencies and Mathematics, 95, pp. 136-146.

Hung, W., Jonassen, D. H. and Liu, R. [2008]: «Problembased learning», in J. M. Spector, J. G. van Merriënboer, M. D., Merrill and M. Driscoll (eds.), Handbook of research on educational communications and technology (3rd ed.), Mahwah (Ney Jersey): Erlbaum.

Larmer, J. and Mergendoller, J. [2010]: «Seven essentials for project-based learning», Educational Leadership, 68 (1), pp. 34-37.

Neville, A. J. [2009, Retrieved, November, 2012]: «Problem-based learning and medical education forty years on. A review of its effects on knowledge and clinical performance. Medical principles and practice: international journal of the Kuwait University», Health Science Centre, 18 (1), pp. 1-9. PMID 19060483.

Schmidt, H. G. [1983]: «Problem-based learning: rationale and description», Medical Education, 17, pp. 11-16. 